\title{
What drives target status decision in emerging markets acquisitions?
}

\author{
Viet Anh Hoang \\ Faculty of Banking, The University of Danang, Danang, Vietnam \\ Man Dang \\ Faculty of Finance, The University of Danang, Danang, Vietnam \\ Ngoc Vu Nguyen \\ The University of Danang, Danang, Vietnam \\ Ngoc Thang Nguyen \\ Faculty of Finance, The University of Danang, Danang, Vietnam, and \\ Darren Henry \\ Department of Economics and Finance, \\ La Trobe Business School, La Trobe University, Australia
}

\begin{abstract}
Purpose - The purpose of this paper is to investigate the effects of cross-country characteristics on acquirers' target status choice in cross-border mergers and acquisitions across 41 emerging markets.

Design/methodology/approach - The paper first reviews the existing literature and develops the related hypotheses, in conjunction with the objectives of this paper. We then describe the data employed, variable measurement and examine the effects of cross-country characteristics on the acquirers' target status choice in cross-border mergers and acquisitions while controlling for firm-level and deal-specific characteristics. The paper continues to conduct the robustness check on cross-country determinants of target status choices using the difference independent variables rather than target country-level variables only.

Findings - This research found that the likelihood of a public firm acquired relative to private one is higher if the target firm is located in countries with stronger government quality, weaker economic freedom, better financial market development and lower cultural distance between the host and home countries. The results suggest that bidders actively assess cross-country characteristics as part of their acquisition planning.

Originality/value - Rather than commonly analysed determinants in the previous research such as firm-and deal-specific attributes, value creation and shareholder protection, this paper indicates that institutional environments and economic conditions are closely associated with acquisition risks and benefits and have direct influences on bidder firms' acquisition bidding planning and target choice decision-making.
\end{abstract}

Keywords Country-level characteristics, Target status decision, Cross-border mergers and acquisitions, Emerging markets, Imperfect factor markets

Paper type Research paper

(C) Viet Anh Hoang, Man Dang, Ngoc Vu Nguyen, Ngoc Thang Nguyen and Darren Henry. Published in Journal of Economics and Development. Published by Emerald Publishing Limited. This article is published under the Creative Commons Attribution (CC BY 4.0) licence. Anyone may reproduce, distribute, translate and create derivative works of this article (for both commercial and non-commercial purposes), subject to full attribution to the original publication and authors. The full terms of this licence may be seen at http://creativecommons.org/licences/by/4.0/legalcode

Viet Anh Hoang, Man Dang, Ngoc Vu Nguyen, and Ngoc Thang Nguyen are senior lecturers at the University of Danang (Vietnam). We thank the participants at the 2019 VICIF Conference and seminars at the University of Danang (Vietnam) and La Trobe Business School (Australia), for very fruitful comments and suggestions. All remaining errors are our own. This research is funded by Funds for Science and Technology Development of the University of Danang under project number B2018-ĐN04-07.
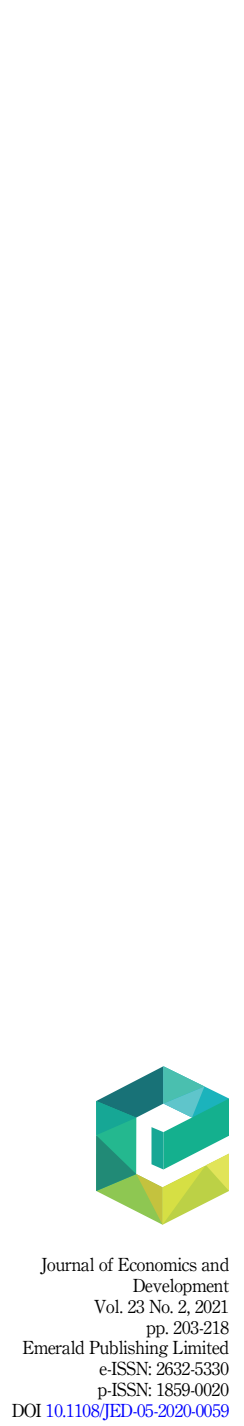
JED

23,2

204

\section{Introduction}

Mergers and Acquisitions (M\&As) are increasingly a large key mode of foreign direct investment (FDI) since the late 1980s. Keeping pace with changes in the global environment, the integration of local markets into the world economy, the liberalization and the development of financial markets, cross-border M\&A deals continue to be major forces for the global economic growth. Bidders are increasingly looking to emerging markets for new investment opportunities. The SDC database shows that on average $42.12 \%$ of targets acquired are publicly listed. Since cross-border acquisitions to emerging markets continue growing and the challenges posed by acquisitions in these markets are broad and diverse, understanding of the motivation and strategic rationale of acquiring public targets versus private targets is worth receiving more attention (Bae et al., 2013).

The existing literature shows that the bidding firms' selection to acquire unlisted or listed firms is determined by characters of firms. Shen and Reuer (2005) report that bidders are not willing to acquire private targets when the deal is outside their core business and when private firms have significant intangible resources or their value of assets is highly uncertain. They also indicate that assessing a target's value can meet significant challenges for acquirers in the case of small and private targets, therefore, when such valuation problems are apparent, bidders are more likely to pursue public targets, for which these difficulties are comparatively less severe. The second stream of literature examines the target status selection decision in association with information asymmetry and suggested that information asymmetry may have a significant impact on the strategy and performance implications of acquisitions. The explanation is that information asymmetry has a certain association with firm and deal characteristics and, thus, affecting target status selection (for instance, Capron and Shen, 2007).

There is also another strand of literature paying attention to country-level factors as the determinants of target selection and acquirer returns. Bae et al. (2013) find country-level transparency as a determinant of target firm selection in cross-border acquisitions. Specifically, they indicate that it is more likely for bidders to buy private targets in lower-transparency countries (higher information asymmetry environment) to yield higher price discount associated with private firms. Feito-Ruiz et al. (2014) indicate that the acquiring firms located in countries with less protection to shareholders and minority shareholders are more likely to acquire listed firms; whereas the higher level of information asymmetry and the less developed the capital market in the acquired firm country, the more likelihood of acquisitions of unlisted firms. Focusing on the relationship between the country-level determinants of target selection and acquirer returns in cross-border acquisitions, John et al. (2010) find that when target countries have a strong protection of minority shareholders, announcement returns of bidders are significantly negative resulting from acquisitions of public target companies and positive in acquisitions of private target companies. Similarly, a number of existing studies find the effects of political risk, geographic and cultural distance on the bidders' returns in association with target status (see Tao et al., 2017).

Drawing from the existing literature, we believe that the relevance of all firm-attributes and of information-based deal attributes may depend on the characteristics of countries, particularly the legal and institutional environment. Our paper makes a great effort in the examination on the decision-making of bidders in cross-border acquisitions across 41 emerging markets over the period from 2000-2015. Specifically, we focus on cross-country determinants of acquirers' target status choice and how this might be affected not only by involved firm and deal attributes but also by the institutional attributes of the host-home countries as well as differences in these institutional characteristics across those countries. Accordingly, we have taken a different approach based on the transaction-nature of crossborder acquisitions, which involves bidders and target countries from different countries and considers differences in country-level attributes and their association with bidders' planning 
and decision-making. Prior studies focus on the role of country-level characteristics in explaining the acquirer return effects associated with the acquisitions of private targets relative to those of public targets. In our study, we expect country-specific factors to be directly associated with target choice decision for bidding firms. As such, our key proposition is that, in the cross-border target selection decision-making, it is a great deal of importance for bidding companies to perform a thorough analysis of the target firm's local regulatory and country institutional environments in order to identify possible gaps in the markets and determine how the acquired firm can play a mediating role, providing access to networks to reduce information asymmetry and afford the acquirer a comfortable position in that environment. If bidding companies are reasonably accurate in their assessment of acquisition risks and benefits, then we subsequently expect country-specific institutional factors to be directly associated with target choice decision for bidding firms. Dang et al. (2018) have provided the similar conclusions for the cross-country determinants of bidder ownership choices. They find that the target country-level characteristics and differences in the institutional attributes between bidder and target countries are informative of bidder acquisition decisions. Their study also suggests that bidders tend to consider cross-country characteristics as part of their acquisition planning. Also examining the role of cross-country factors and the bidder acquisition decision-making, our paper differentiates from Dang et al. (2018)'s study by putting more attention to target country-level attributes as the determinants of target status selection.

Following the existing literature, country-level characteristics regarding (1) government quality, (2) economic freedom, (3) financial development and (4) cultural distance are suggested as key cross-country determinants of investment motives and acquisition sources of value for foreign bidders and, thus, play a vital role in acquirers' takeover decision-making across emerging market economies. Therefore, if country-specific attributes or variations across such countries provide potential acquisition motives, then it is reasonable to expect that they should also be correlated with the bidders' decision-making.

This paper broadens the existing literature on acquisitions with three significant contributions. Firstly, our paper focuses on the country-specific determinants on bidders' behaviour generally and target status selection in particular, and cross-country differences, which are better reflections of perceived acquisition risks and benefits. Acquirers may confront certain challenges and risks when adapting to a different institution and operating in a new country. Investing in the emerging markets may carry more risks than those associated with investing in the developed markets, typically and substantially political risks and social risks. Emerging countries have been going through the institutional transformation and have experienced certain market imperfections. However, as any twofaced implication, for those with a taste for risk, emerging economies can provide great promises. Secondly, previous studies have focused on either firm-level and deal-specific determinants for examining the target status choice decision in the correlation with the shareholder returns or firm valuation. Our analysis fills in the gap of the literature when concentrating on the target status selection decision-making of bidding companies specifically by examining cross-country determinants and particularly target country characteristics. Our attention is on whether target country-level factors including government quality, economic freedom, financial development and cultural distance play the pivotal role in the acquisition decision of private targets or public targets and whether the variations in institutional environment characteristics between bidder and target companies are also related to bidders' target status choices.

Thirdly, this paper contributes to the current emerging market literature (Deng and Yang, 2015; Lebedev et al., 2015) by looking into the emerging market targets and extending at a large-scale level across 41 emerging markets. Developed economies have experienced a stagnant growth, especially after the 2007-2008 global financial crisis, thus,
Target status decision and market acquisition 
JED

23,2

206

investors have looked elsewhere to reap the gains that Western markets used to offer. Besides the faster growth rate of emerging markets, the improvement in liquidity, capital raising and larger labour force also make the emerging markets more attractive than their developed counterparts. Yet, investing in the emerging markets may carry more risks than those in the established markets when the emerging countries have been going through the institutional transformation and have experienced certain market imperfections. However, for those with a taste for risk, emerging economies can provide great promises. As cross-border acquisitions into emerging markets continue to grow, understanding of the motivation and strategic rationale of these foreign acquisitions is deserving more attention.

The remainder of the paper is organized as follows. In the next section, we review the existing literature and develop the related hypotheses, in conjunction with the objectives of this paper. Section 3 describes the data employed and variable measurement, while the empirical results are presented and discussed in Section 4. Section 5 concludes our study.

\section{Hypothesis development}

Existing literature indicates that variation in government quality significantly affects the flow of FDI to developing and emerging countries (Buchanan et al., 2012). Alexandridis et al. (2011) find that target countries with better quality of laws and regulations tend to experience more cross-border acquisitions. Dang et al. (2018) examine the importance of the target countries' government quality for the acquirers' ownership decisions and find that bidders tend to acquire higher ownership of target firms operating in countries with better government quality. The target countries with lower levels of government quality might have weaker and unclear law and regulation environment, less information transparency, more uncertainty and political risks to business activities. In such an opaque information environment, local information on public targets would not be reliable or useful and might not be much different from information on private targets; therefore, the motivation to buy a public target will be weakened, and it would not be worth paying an extra premium for public targets in this case (Capron and Shen, 2007). Motivated by the above discussion with respect to the role of target government quality, it can be hypothesized that:

H1. The higher the target country government quality, the greater probability of acquiring a public target firm relative to a private target firm.

Regarding economic freedom, the impacts of economic freedom in cross-border mergers and acquisitions, particularly for acquirers' acquisition decisions have been clearly surveyed in the current literature (Li et al., 2018). According to Bhagat et al. (2011), the higher degree of economic freedom means better legal structure and security of property rights, capital raising and capital control with greater international trade openness, which is believed to decrease the risks and uncertainty in the likelihood of investing in the target countries. A less restrictive international trade policy and the increased participation in trade openness of target countries create greater opportunities to welcome foreign capital flows from new markets and boost potential acquisition benefits. Hence, acquiring target companies which are located in countries with better economic openness and less restrictive international trade policy are expected to create more value when the target firms are unlisted. Accordingly, the following research hypothesis is proposed:

H2. The higher the target country degree of economic freedom, the lower probability of acquiring a public target firm relative to a private target firm.

Previous studies have investigated the influence of financial development on target status selection in cross-border acquisitions (Capron and Shen, 2007; Feito-Ruiz et al., 2014). 
According to Feito-Ruiz et al. (2014), underdeveloped financial markets in target countries make unlisted targets encounter more difficulties and more costly in obtaining external financing and less available liquidity. As a result, unlisted firms are more likely to be offered a discount in the offer price, which, in turn, boosts the probability of unlisted firms acquired by cross-border bidders. The current literature reaches a conclusion that the less developed the capital market in the target country, the greater the probability unlisted firms get acquired. Bae et al. (2013) find that well-developed financial systems provide an active market for shares of public firms and, hence, bidding firms are willing to acquire public targets located in a country with better financial market development in order to potentially get premium benefits from its shares in the readily available stock market with lower acquisition risks. Therefore, we posit that:

H3. The higher the target country level of financial development, the greater probability of acquiring a public target firm.

Prior studies have also focused on the influence of cultural distance on cross-border acquisition performance and process (Weber et al., 1996; Morosini et al., 1998), but the results are mixed. National and organizational cultural barriers can be major obstacles to achieve benefits for post-combination integration process. A high level of cultural distance between firms is likely to cause cultural ambiguity and process loss when different cultures collide during the post-acquisition process, whereas international acquisitions may be particularly difficult to integrate because they require "double layered acculturation", whereby not only corporate cultures but also different national cultures have to be combined. Empirically, however, Morosini et al. (1998) find that acquisitions perform better if there is a larger degree of national cultural distance between the two involved firms. Although there is no consensus on the exact impact of cultural distance on cross-border acquisition performance, the existing literature agrees that high cultural distance increases the level of uncertainty and risks, especially in the case of cross-border deals when acquirers enter into a foreign market with different language, legal and governance systems as well as national cultural barriers (Kang and Jiang, 2012). Accordingly, we suggest the final hypothesis as follows.

H4. The higher the level of cultural distance between the bidder and target country, the lower probability of acquiring a public target firm relative to a private firm.

\section{Data and sample description}

\subsection{Data and sample selection}

A comprehensive sample of completed cross-border acquisitions involving target firms over the period between January 2000 and December 2015, across 41 emerging markets, was taken from the Thomson Reuters SDC Platinum database. An initial set of 53,987 completed crossborder acquisition announcements in these emerging countries was obtained. These countries were selected based on the emerging markets-related new classification introduced by BBVA Research (2014).

Following the literature, we require companies to acquire a stake in target companies no less than $5 \%$ and do not hold less than $5 \%$ after the deal is completed. Also, in order to address sample selection bias, we exclude observations in which multiple firms acquire the same company on the same day. For an acquisition to remain in the sample, we require that the transaction value to be at least US $\$ 1.0$ million and that financial data for the acquirers and target firms be available on Datastream, Thomson Reuters Worldscope or Bureau van Dijk's Mint Global databases, though there are still missing values across different variables. Finally, we have removed transactions where the target's listing status was something other than public or private. After screening criteria and deleting acquisition observations with 
JED

23,2

208

missing values, the final sample consisted of 16,806 cross-border acquisition transactions involving 41 different target countries in emerging markets.

\subsection{Model, variables, and measures}

Our model is given as follows [1]:

$$
\text { Pubtarget }_{i, t}=\beta_{0}+\beta_{1} I E_{j, t-1}+\beta_{2} \text { CONTROLS }_{t-1}+\gamma_{s}+\delta_{t}+\Omega_{g}+\zeta_{i, t}
$$

where,

3.2.1 Dependent variable (Pubtarget). The dependent variable (Pubtarget) is acquirers' target status choice in cross-border acquisitions, taking the value of one if the target is publicly listed and zero otherwise.

3.2.2 Institutional environment variables (IE). The first explanatory variable is quality of government (GovQuality) derived from Kaufmann et al. (2009) and from the World Bank's six Governance Indicators. The second key variable studied refers to the degree of economic freedom (EcoFreedom). This study uses the index published by the Fraser Institute, which measures the country's level of economic freedom. The next key explanatory variable is financial development (FinDevelop). We follow Gries et al. (2009) and Dang et al. (2018) to employ the principal component analysis method to create a wide-ranging index of financial development constructed from the four widely used financial development indicators, covering M2, liquid liabilities, total domestic credit and domestic credit to the private sector. The last key explanatory variable, cultural distance (CulDistance), captures the difference in the national culture between acquiring firm country and target firm country. This index is computed using Kogut and Singh (1988)'s method from Hofstede's six cultural dimensions (Hofstede, 1994).

3.2.3 Control variables (CONTROL). A number of control variables that could possibly affect acquirers' target status choices are incorporated in our multivariate setting, representing (1) the characteristics of acquisition deals: Relatedness (Capron and Shen, 2007), Toehold (Kim, 2012) and Cash (Fuller et al., 2002); (2) firm-level variables: Size (Kim, 2012), RelSize (Andriosopoulos and Yang, 2015), Public bidder (Capron and Shen, 2007) and Emerging bidder (Dang et al., 2018). Moreover, carrying out a cross-country study of acquisitions considerably depends on economic conditions across countries; therefore, it is expected that bidders are more probable to acquire a public target firm if the target is located in countries with stronger economic eminence and prosperity, which can be proxied by GDP per capita (GDP per capita) and GDP growth (GDP Growth) variables.

In order to control for year, industry and geographic effects, we respectively include year $\left(\delta_{t}\right)$, industry $\left(\gamma_{s}\right)$, and host country geographic location $\left(\Omega_{g}\right)$ in all model specifications.

\subsection{Characteristics of the sample}

Table 1 reports the summary statistics on the characteristics of acquisition deals in rank order by total number of deals [2]. As shown in Table 1, the percentage of public targets varies from $0 \%$ (i.e. Algeria, Qatar, and Uzbekistan) to $100 \%$ (i.e. Brazil, Russia, and Turkey). On average, $42.12 \%$ of targets acquired are publicly listed. Also, target firms in large emerging market countries (India, China and Mexico) and new emerging markets (Malaysia and Indonesia) are more attractive to cross-border bidders than those located in the other markets. Moreover, cross-border bidders tend to prefer noncash deals and outside-core-business (nonrelated) acquisitions. Interestingly, the number of hostile deals is found to be startlingly rare, which represents $0 \%$ in the most of hostile deals in emerging market acquisitions. There is a big difference in the proportion of toehold-related deals across target countries. For example, only about $3.57 \%$ of foreign bidders hold the target firms' shares at the time of acquisitions in Indonesia, while the rate for Colombia is up to $48.84 \%$. 


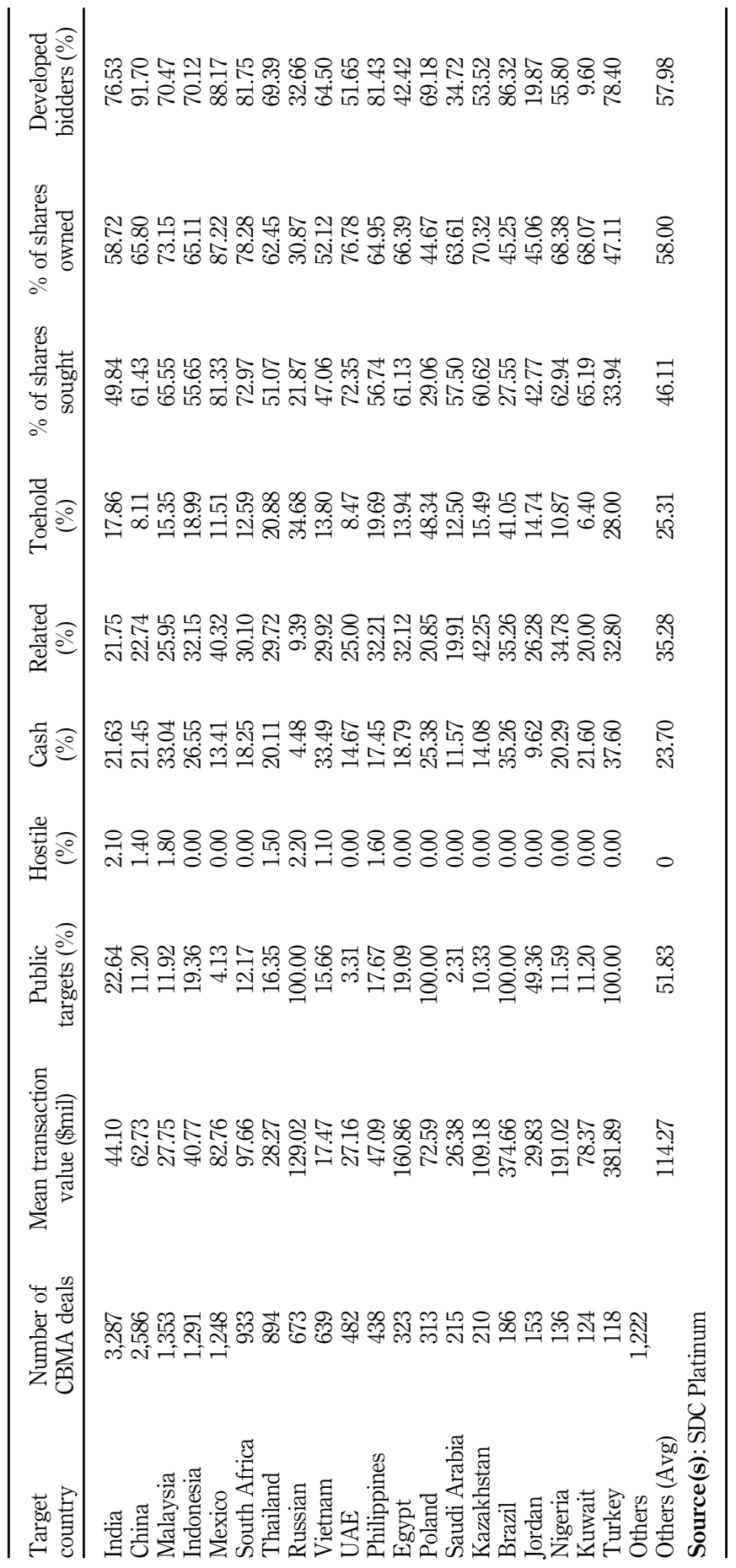

Target status decision and market acquisition

209

Table 1. Data on completed cross-border mergers and acquisitions by top-20 countries ranked by number of deals 
JED

23,2

210

Table 2 reports the industry distribution of bidders and targets. It can clearly be seen that there is a diversification across target and acquirer industries, though financial services make up for the largest proportion. Foreign bidders operate in financial services as the most, followed by manufacturing and consumer products industries. In addition, they prefer target firms involved in the same areas of operations, which indicate that acquirers tend to avoid targets outside of their core business.

Table 3 describes summary statistics on characteristics of country-level variables according to target status over the $2000-2015$ period. The results indicate that bidders tend to seek publicly held target firms operated in countries with better control of corruption, stronger economic freedom, bigger restrictions on international trade, higher financial market development, greater GDP growth,and less organized and ordered society. Regarding the variation in country-level characteristics between bidder and target countries, bidders prefer publicly held target firms when listed target firms' countries have worse government quality, weaker economic freedom, less-developed financial market and higher cultural distance between bidders and targets.

\section{Regression results}

\subsection{Cross-country determinants of target status choices}

This section firstly examines the influences of the cross-country characteristics on target status choices by undertaking binominal logistic regressions of the target selection on the country-level variables and controlling for firm-level and deal-specific variables. The results of five logit models are presented in Table 4. As seen from column (1), we find strong evidence supporting Hypothesis H1. The coefficient on the Target GovQuality variable is positive and statistically significant suggesting higher likelihood of acquiring publicly held target firms located in countries with stronger government quality. One of the key merits of acquiring a public target firm is that the acquirer can access public financial information of its target firm and the local information would be reliable when target country has a strong government quality (Capron and Shen, 2007). Therefore, if bidders are reasonably accurate in their assessment of acquisition by reliable and useful information on public targets, they will prefer public target firms to avoid the overpayment as for private target firms.

The result from column (2) shows the negative and statistically significant coefficient on the Target EcoFreedom, which is in line with Hypothesis H2. The finding suggests that the probability of a public target acquiring deal is negatively correlated with the degree of economic freedom in the target country and that the higher the economic freedom, the lower the probability of acquiring publicly held firms. It is proposed that fewer frictions and market imperfections in acquisitions of targets from countries with strong economic freedom, which is associated with

Table 2.

Industry distribution of completed crossborder mergers and acquisitions

\begin{tabular}{llrrrr}
\hline & & \multicolumn{2}{c}{ Target industry } & \multicolumn{2}{c}{$\begin{array}{c}\text { Bidder industry } \\
(\%)\end{array}$} \\
& \multicolumn{1}{c}{ SIC codes } & \multicolumn{1}{c}{ Deals } & \multicolumn{1}{c}{ Deals } & $\%$ \\
\hline 0000-999 & Food products & 191 & 1.61 & 231 & 1.35 \\
$1,000-1999$ & Mining and construction & 1961 & 11.61 & 1294 & 7.55 \\
$2000-2999$ & Consumer products & 2588 & 15.46 & 1805 & 10.53 \\
$3000-3999$ & Manufacturing & 2766 & 16.48 & 2062 & 12.03 \\
$4000-4999$ & Utilities and transportation & 1782 & 10.63 & 1126 & 6.57 \\
$5000-5999$ & Wholesale, retail, and some services & 1122 & 6.61 & 644 & 3.76 \\
$6000-6999$ & Financial services & 3025 & 18.14 & 7883 & 45.98 \\
$7,000-7,999$ & Personal and business services & 2361 & 13.90 & 1432 & 8.35 \\
8000-8999 & Miscellaneous & 1010 & 5.55 & 669 & 3.90 \\
& & & & &
\end{tabular}




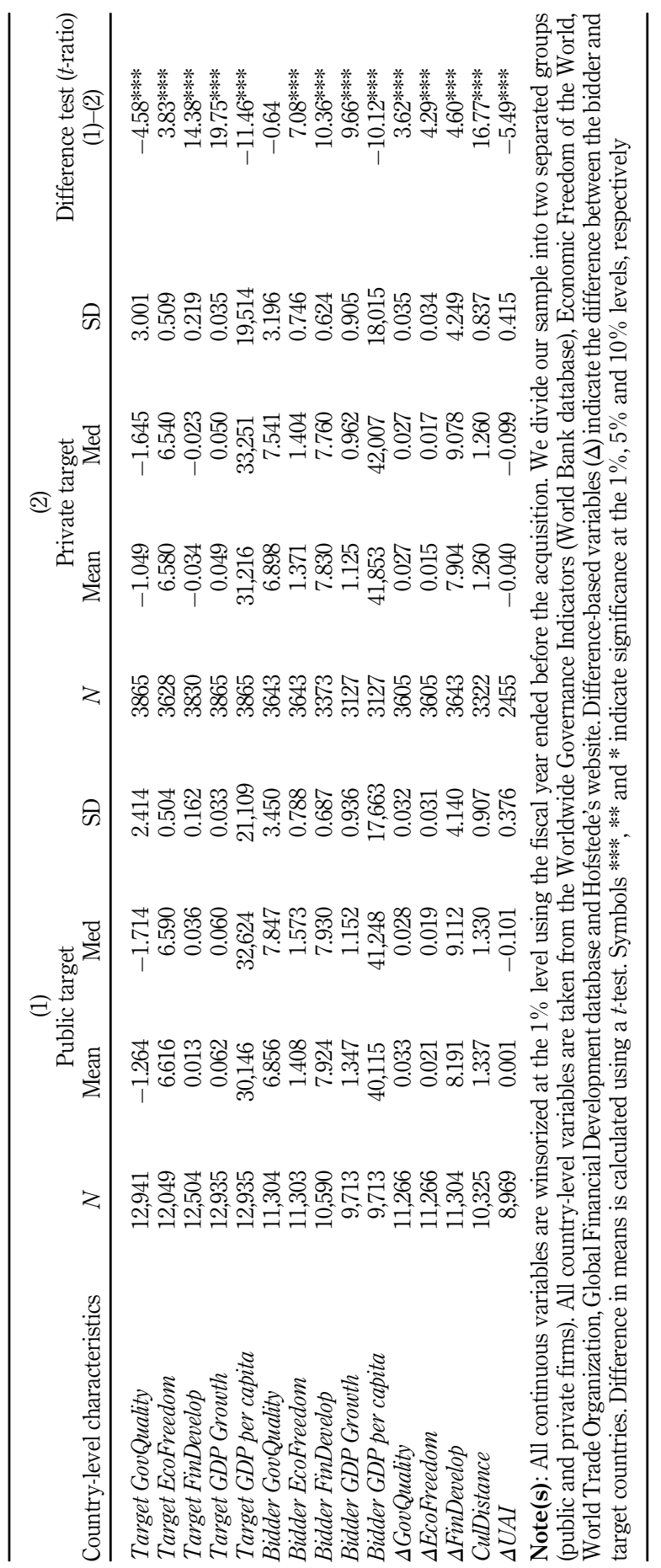

Target status decision and market acquisition

211

Table 3. Country-level characteristics and target status preferences 
JED

\section{2}

Henting

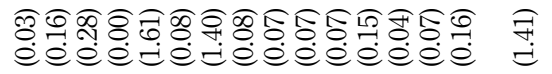

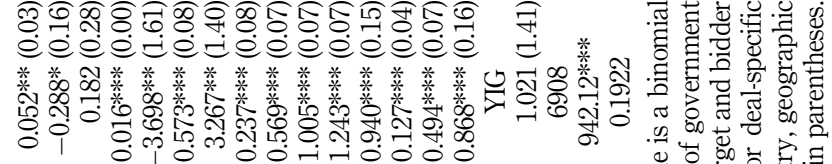

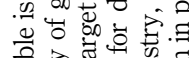

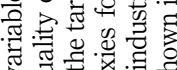

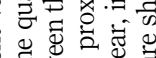

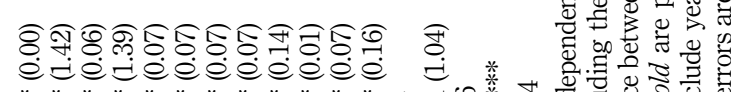

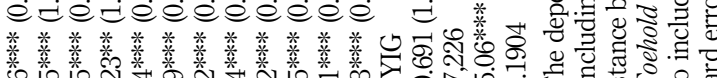
은

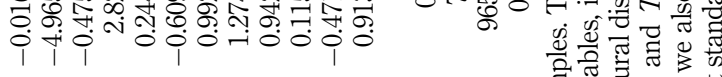

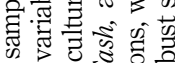
政

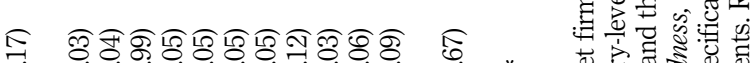

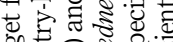
* *

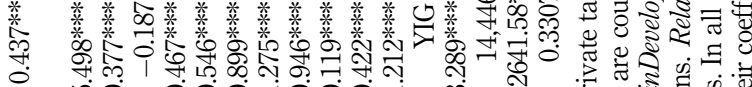
एं to

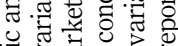

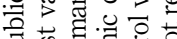

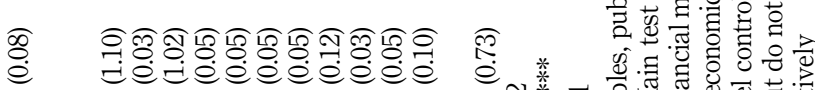

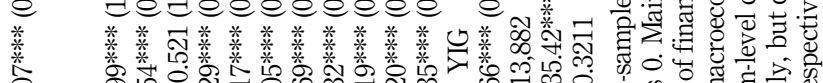

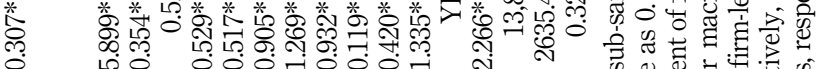

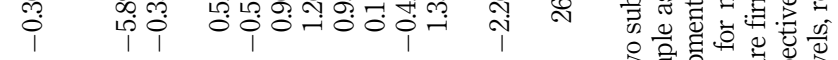

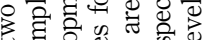

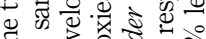

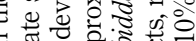

产 ฮ

Table 4.

Cross-country determinants of target status choices in crossborder acquisitions 
more efficient markets and stronger economic growth, leading to the target countries' lower cost of capital and agency costs. Therefore, if foreign bidders realize lower cost of capital and agency costs with less investment risks in high economic freedom target countries, they prefer private firms to public firms in order to experience the acquisition discount, benefits from greater announcement wealth effects and other higher growth potentials.

Our results reported in Column (3) also support Hypothesis H3. Column (3) indicates the significantly positive coefficient on the Target FinDevelop, which means that the probability of acquiring publicly-held firms is higher in target countries with more-developed financial markets. This finding is consistent with Bae et al. (2013) that well-developed financial systems provide an active market for shares of public firms, thus bidding firms are willing to acquire a public target located in a country with financial market development in order to potentially get premium benefits from its shares in the readily available stock market with lower acquisition risk.

In column (4), the influence of the difference in the national culture between home and host countries on acquirers' target status selection is examined. The significantly negative coefficient for the CulDistance variable suggests that the higher the cultural distance, the lower likelihood of acquiring a publicly listed firm, and, therefore, it is in line with Hypothesis H4. Accordingly, the higher level of cultural distance means more differences in the political institutions, economic and social institutions between bidder and target country. This leads to greater risks, more obstacles to business activities and higher information asymmetry in the target country, which are considered as potential compensated factors for greater gains by acquiring a private firm. Therefore, acquirers are less likely of acquiring public target firms when there is a larger cultural difference between the host and home countries.

After each key explanatory variable is examined separately, all of the variables are combined together in a full model in column (5). The results are generally consistent with the findings above except for the financial market development variable (the coefficient is still positive but statistically insignificant).

\subsection{Robustness test}

We continue to conduct the robustness check on cross-country determinants of target status choices using the difference independent variables rather than target country-level variables only. Accordingly, the main test variables include the difference in the quality of government ( $\Delta$ GovQuality); difference in the quality of economic freedom $(\Delta$ EcoFreedom); difference in the development of financial markets ( $\triangle$ FinDevelop) and difference in the uncertainty avoidance index $(\triangle U A I)[3] . \Delta(G D P$ Growth) and $\Delta \log (G D P$ per capita) are proxies for the difference in macroeconomic conditions between the two countries. We report our results in Table 5 .

As reported in column (1) of Table 5, the significantly positive coefficient for the $\Delta$ GovQuality variable proposes that the larger the government quality gap between the target and bidder countries, the greater the probability of acquiring public target firms relative to private firms. In column (2), the significantly positive coefficient for $\Delta$ EcoFreedom variable supports our idea that the likelihood of acquiring public target firms is higher when target countries have the lower degree of economic freedom relative to bidder countries. Column (3) shows the negative and statistically significant coefficient for the $\Delta$ FinDevelop variable. This result supports our hypothesis and identifies that if target firms are located in countries with stronger financial market development relative to the bidder countries, there is a greater probability of acquiring public target firms. Column (4) examines if cultural distance between the two countries are associated with acquirers' target status selection. The significant negative coefficient for the $\triangle U A I$ variable indicates that if the target and bidder countries share similar social standards and then there is lower cultural distance between two countries, the bidders are more willing to acquire the public firm targets. The result again supports our prior findings. 
JED

\section{4}

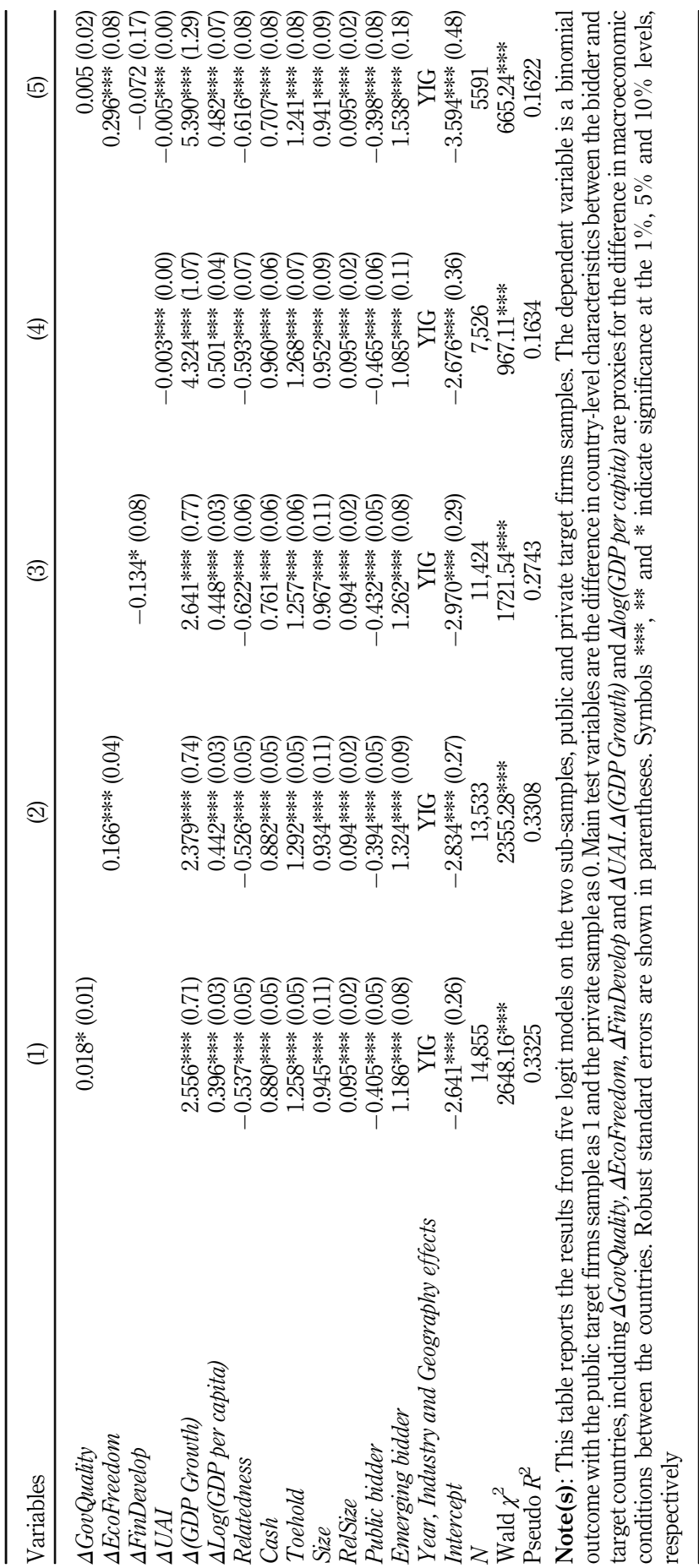

Table 5.

Robustness on crosscountry determinants of target status choices using the difference independent variables

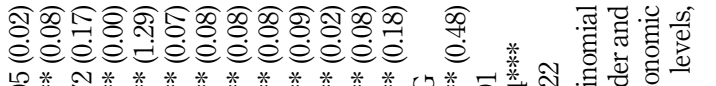

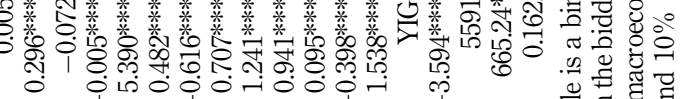
年。

记

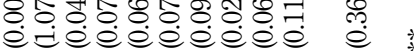

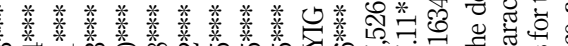
। 节苞

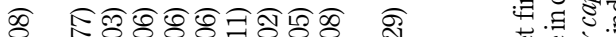

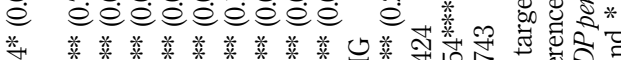

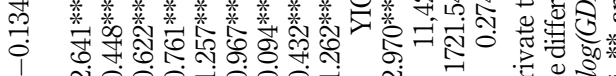
岂乌 㓂 0

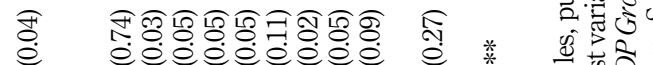

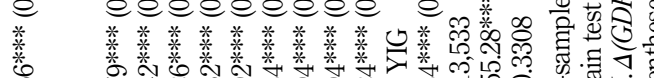

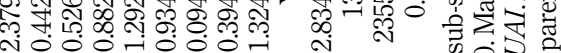
ส 诺 胥胥

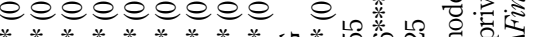

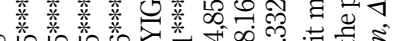

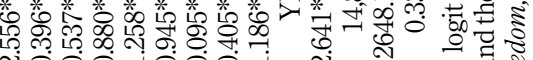
Nơัก 空空 过 空

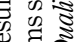

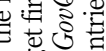
: $\rightarrow$ 记 怘. के है ב.气 


\section{Conclusion}

This study has examined major factors that determine the target status choice of public listed firms versus private firms by bidding firms in cross-border mergers and acquisitions across 41 emerging markets. After controlling for firm-level and deal-specific characteristics, we find that target country-level characteristics and differences in cross-country factors between the home and host countries are associated with acquirers' target status selection.

The findings of the paper contribute two important implications. Regarding theoretical implications, this study emphasizes the literature on the acquisitions with the importance of cross-country characteristics for acquirers' acquisition decision-making generally and target status selection particularly. Rather than commonly analysed determinants in the previous research such as firm- and deal-specific attributes, value creation and shareholder protection, this paper indicates that institutional environments and economic conditions are closely associated with acquisition risks and benefits and have direct influences on bidder firms' acquisition bidding planning and target choice decision-making.

In terms of practical implications, while previous studies are primarily devoted to only some large emerging host economies, we examine the decision on target selection by considering a comprehensive sample consisting of 41 emerging markets, which allows us to generalize the statistical results and conclusions to the entire emerging markets context. The findings shed light on benefits being facilitated by mechanisms such as economic openness, international trade capabilities and well-functional financial market, together with the perception of cultural distance as informative sources of bidder acquisition decisions. Accordingly, the study proposes that foreign acquirers actively assess and analyse cross-country institutions as part of their acquisition planning, while domestic target firms identify advantages and disadvantages of their position in the environment for negotiations in the acquisition deals.

It is potentially that managerial opportunism and differences in information availability on private relative to public firms influence both the acquirer's choice of target as well as its performance. We leave this possibility for future research.

\section{Notes}

1. Also see Table A1 for the definition of variables.

2. Also see Table A2 for the correlation matrix.

3. More details about this $U A I$ index, see Table A1.

\section{References}

Alexandridis, G., Mavrovitis, C.F. and Travlos, N.G. (2011), "How have M\&As changed? Evidence from the sixth merger wave", The European Journal of Finance, Vol. 18 No. 8, pp. 663-688.

Andriosopoulos, D. and Yang, S. (2015), "The impact of institutional investors on mergers and acquisitions in the United Kingdom”, Journal of Banking and Finance, Vol. 50, pp. 547-561.

Bae, S.C., Chand, K. and Kim, D. (2013), "Determinants of target selection and acquirer returns: evidence from cross-border acquisitions", International Review of Economics and Finance, Vol. 27, pp. 552-565.

Bhagat, S., Malhotra, S. and Zhu, P. (2011), "Emerging country cross-border acquisitions: characteristics: acquirer returns and cross-sectional determinants", Emerging Markets Review, Vol. 12, pp. 250-271.

Buchanan, B., Le, Q. and Rishi, M. (2012), "Foreign direct investment and institutional quality: some empirical evidence”, International Review of Financial Analysis, Vol. 30 No. 5, pp. 81-96.

Capron, L. and Shen, J.C. (2007), "Acquisition of private vs. public firms: private information, target selection, and acquirer returns”, Strategic Management Journal, Vol. 28, pp. 891-911.
Target status decision and market acquisition 
JED

23,2

Dang, M., Henry, D., Nguyen, M.T. and Hoang, V.A. (2018), "Cross-country determinants of ownership choices in cross-border acquisitionsi: evidence from emerging markets", Journal of Multinational Financial Management, Vol. 44, pp. 14-35.

Deng, P. and Yang, M. (2015), "Cross-border mergers and acquisitions by emerging market firms: a comparative investigation", International Business Review, Vol. 24, pp. 157-172.

Feito-Ruiz, I., Fernández, A.I. and Menéndez-Requejo, S. (2014), "Determinants of the acquisition of listed versus unlisted firms in different legal and institutional environments", Applied Economics, Vol. 46, pp. 2814-2832.

Fuller, K., Netter, J. and Stegemoller, M. (2002), "What do returns to acquiring firms tell us? Evidence from firms that make many acquisitions", Journal of Finance, Vol. 57 No. 4, pp. 1763-1793.

Gries, T., Kraft, M. and Meierrieks, D. (2009), "Linkages between financial deepening, trade openness and economic development: causality evidence from Sub-Saharan, Africa”, World Development, Vol. 37, pp. 1849-1860.

Hofstede, G. (1994), “The business of international business is culture”, International Business Review, Vol. 3 No. 1, pp. 1-14.

John, K., Freund, S., Nguyen, D. and Vasudevan, G. (2010), "Investor protection and cross-border acquisitions of private and public targets", Journal of Corporate Finance, Vol. 16 No. 3, pp. 259-275.

Kang, Y. and Jiang, F. (2012), "FDI location choice of Chinese multinationals in East and Southeast Asia: traditional economic factors and institutional perspective", Journal of World Business, Vol. 47 No. 1, pp. 45-53.

Kaufmann, D., Kraay, A. and Mastruzzi, M. (2009), "Governance matters VIII: aggregate and individual governance indicators 1996-2008”, Working Paper 4280, World Bank Policy Research, Washington, DC.

Kim, W. (2012), "Investor protection and the mode of acquisition: implications for ownership dilution and formation of pyramids", Financial Management, Vol. 41, pp. 55-93.

Kogut, B. and Singh, H. (1988), "The effect of national culture on the choice of entry mode", Journal of International Business Studies, Vol. 19 No. 3, pp. 411-432.

Lebedev, S., Peng, M.W., Xie, E. and Stevens, C.E. (2015), "Mergers and acquisitions in and out of emerging economies", Journal of World Business, Vol. 50, pp. 651-662.

Li, T., Xue, Y., Lu, J. and Li, A. (2018), "Cross-border mergers and acquisitions and the role of free trade agreements", Emerging Markets Finance and Trade, Vol. 54 No. 5, pp. 1096-1111.

Morosini, P., Shane, S. and Singh, H. (1998), "National cultural distance and cross-border acquisition performance”, Journal of International Business Studies, Vol. 29 No. 1, pp. 137-158.

Shen, J.C. and Reuer, J.J. (2005), "Adverse selection in acquisitions of small manufacturing firms: a comparison of private and public targets", Small Business Economics, Vol. 24 No. 4, pp. 393-407.

Tao, F., Liu, X., Gao, L. and Xia, E. (2017), "Do cross-border mergers and acquisitions increase shortterm market performance? The case of Chinese firms", International Business Review, Vol. 26, pp. 189-202.

Weber, Y., Shenkar, O. and Raveh, A. (1996), "National and corporate culture fit in mergers/ acquisitions: an exploratory study", Management Science, Vol. 42 No. 8, pp. 1215-1227.

\section{Further reading}

Reuer, J.J. and Ragozzino, R. (2008), “Adverse selection and M\&A design: the roles of alliances and IPOs”, Journal of Economic Behavior and Organization, Vol. 66, pp. 195-212.

\section{Corresponding author}

Viet Anh Hoang can be contacted at: anhhdv@due.edu.vn 
Appendix

Variable

Description and source

Dependent variable

Pubtarget An indicator variable taking on the value of one if the target firm is publicly listed firm and zero otherwise (Source: SDC Platinum)

Country-level variables

GovQuality A country's quality of government. It is a combined score derived from six dimensions of governance, including (1) The rule of law, (2) regulatory quality, (3) political stability and absence of violence, (4) government effectiveness, (5) voice and accountability and (6) control of corruption. Higher values indicate greater quality of government (Source: World Bank)

EcoFreedom A country's quality of economic freedom. The index measures the country's degree of economic freedom in five wide-ranging areas: (1) Size of government, (2) Legal structure and security of property rights, (3) Access to sound money, (4) Freedom to trade internationally and (5) Regulation of credit, labour and business (Source: Fraser Institute)

FinDevelop This index measures the financial development of a country and constructed from the commonly used four financial development indicators in the literature: (1) Log of M2 to GDP, (2) Log of liquid liabilities to GDP (M3 to GDP), (3) Log of total domestic credit provided by the banking sector to GDP and (4) Log of domestic credit to the private sector to GDP (Source: World Bank)

CulDistance This index measures cultural distance between a home and a host country. It is a combined score derived from six dimensions of Hofstede's national culture, including (1) power distance, (2) individualism versus collectivism, (3) masculinity versus femininity, (4)

Uncertainty Avoidance Index, (5) Long- term versus short-term normative orientation and (6) indulgence versus restraint (Source: Hofstede's website)

UAI This index reflects the amount that people prefer to be governed by rules, laws and standard operating procedures and accept uncertainty or ambiguity. Culture with a high UAI index prefer things to be well ordered, planned ahead and run to time, while a low UAI score suggests a society that is more flexible and relaxed and does not worry when things go wrong (Source: Hofstede's website)

GDP Growth Annual percentage growth rate of gross domestic product (Current US\$) (Source: World Development Indicators, World Bank)

GDP per capita Gross domestic product per capita (Constant, 2005 US\$) (Source: World Development Indicators, World Bank)

\section{Deal-specific variables}

Relatedness An indicator variable taking on the value of one if the target and the acquirer are in same areas of operations and zero for unrelated acquisitions (Source: SDC Platinum)

Cash A dummy that is one if an acquisition is paid by cash and zero if it is by an acquirer's stock or a mixed cash and stock (Source: SDC Platinum)

Toehold The percentage of target equity held by the bidder before the acquisition (Source: SDC Platinum)

Firm-level variables

Size Logarithm of total assets of the target in the fiscal year ended before the announcement of the deal in US\$ $m$ (Source: Worldscope, Mint Global)

RelSize A ratio of the transaction value to total assets of the bidder (Source: Worldscope, Mint

Public bidder An indicator variable taking on the value of one if the acquirer is a publicly listed firm and An indicator variable taking on the value
zero otherwise (Source: SDC Platinum)

Emerging An indicator variable taking on the value of one if acquirers come from emerging market bidder economies and zero otherwise (Source: SDC Platinum)

Target status decision and market acquisition 
JED
23,2

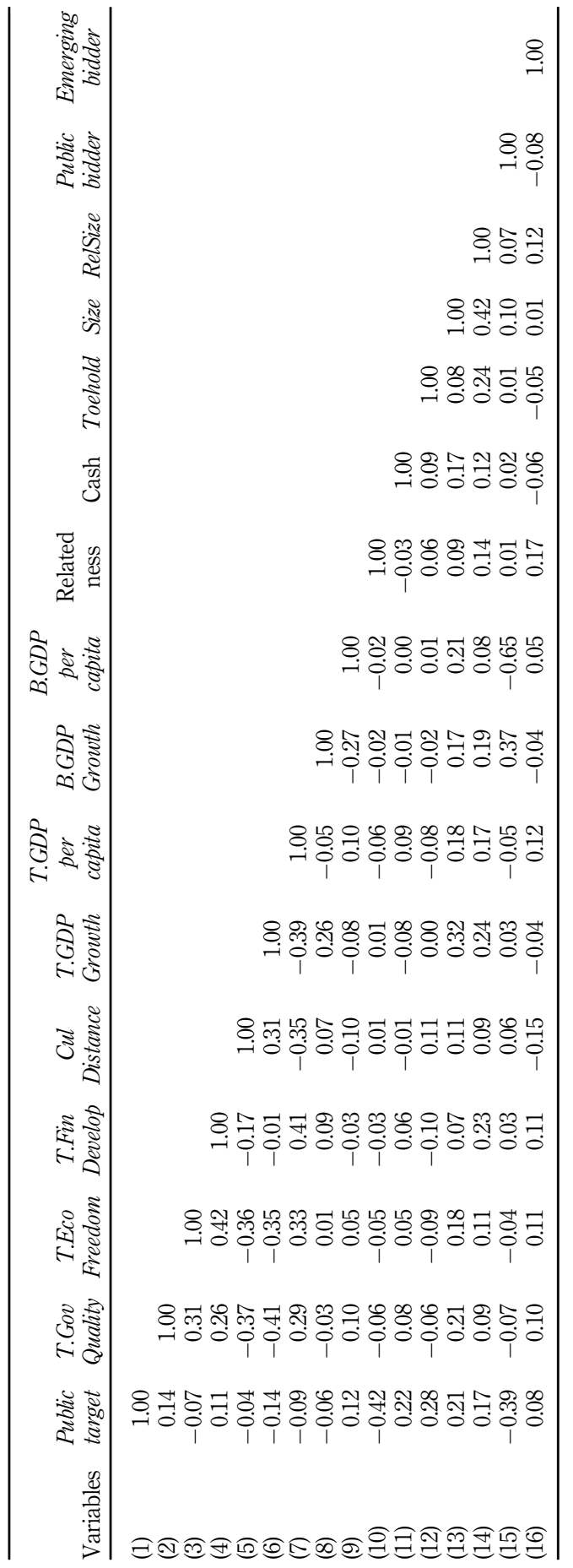

Table A2.

Correlation matrix

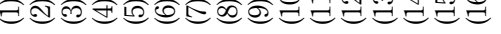

